\title{
PERBANDINGAN SISTEM PENGUKURAN KINERJA PERUSAHAAN
}

\author{
Freddy Simbolon \\ Management Department, School of Business Management, BINUS University \\ Jln. K.H. Syahdan No.9, Palmerah, Jakarta Barat 11480 \\ freddysimbolon@hotmail.com; freddysimbolon@binus.ac.id
}

\begin{abstract}
Corporate performance is a measure of the level of success in managing resource company to create value for share holders and stakeholders. Many of the company's performance measurement system can be used, but the future of performance measurement systems are no longer limited only to the measurement of financial performance, yet more comprehensive and integrated to non-financial aspects of the coverage of measurements on the internal and external environment. There are three performance measurement system that meets these criteria is the BSC, IPMS, and Prism. This research method is using descriptive method of analysis. This study aims to assess the three systems that get the best system to choose. All three systems have advantages and disadvantages, so the best option is a performance measurement system compatibility with the company's condition and capabilities of decision makers.
\end{abstract}

Keywords: Performance Measurement System, BSC, Performance Prism, IPMS

\begin{abstract}
ABSTRAK
Kinerja perusahaan merupakan ukuran tingkat keberhasilan manajemen dalam mengelola sumber daya perusahaan guna menciptakan nilai bagi pemegang saham atau stakeholders. Banyak sistem pengukuran kinerja perusahaan dapat digunakan, namun sistem pengukuran kinerja masa depan tidak lagi terbatas pada pengukuran kinerja keuangan semata, namun lebih komprehensif dan terintegrasi pada aspek non keuangan dengan cakupan pengukuran pada lingkungan internal dan eksternal perusahaan. Terdapat tiga sistem pengukuran kinerja yang memenuhi kriteria tersebut yaitu BSC, IPMS, dan Prims. Metode penelitian ini menggunakan metoda deskriptif analisis. Penelitian ini bertujuan untuk menilai ketiga sistem tersebut sehingga mendapatkan sistem terbaik untuk dipilih. Ketiga sistem tersebut memiliki kelebihan dan kekurangan, sehingga pilihan terbaik adalah kecocokan sistem pengukuran kinerja dengan kondisi perusahaan dan kapabilitas pengambil keputusan.
\end{abstract}

Kata kunci: Sistem Pengukuran Kinerja, BSC, Performance Prism, IPMS 


\section{PENDAHULUAN}

Bila ditinjau dari sisi keuangan, kinerja perusahaan adalah ukuran tingkat keberhasilan manajemen dalam mengelola sumber daya keuangan perusahaan, terutama pada pengelolaan investasi sebagai upaya untuk menciptakan nilai bagi pemegang saham (Elizabeth, 2000). Selain itu menurut (Parawiyati dan Baridwan, 1998), kinerja perusahaan tersebut merupakan hasil dari serangkaian proses bisnis dengan mengorbankan berbagai sumber daya, baik sumber daya manusia maupun keuangan perusahaan. Di pasar modal, para investor menilai tingkat kinerja saham perusahaan menggunakan parameter laba akuntansi dan arus kas. Untuk keadaan pasar modal Indonesia pertimbangan investasi masih banyak didasarkan pada informasi non-akuntansi.

Terdapat tiga model pengukuran kinerja yang paling umum digunakan oleh sebagian besar perusahaan, yaitu Balanced Scorecard, Integrated Performance Measurement System (IPMS), dan Performance Prism, namun dari ketiga model tersebut, Balanced Scorecard adalah model sistem pengukuran kinerja yang paling populer dewasa ini (Neely et al, 1995). Performance Prism ini karena metode ini mengukur semua aspek yang berhubungan dengan stakeholder yang meliputi kepuasan maupun kontribusi dari para stakeholder tersebut yang tentunya sangat berpengaruh bagi perusahaan, sehingga dengan diterapkannya metode ini diharapkan kelangsungan hidup perusahaan dalam jangka panjang akan lebih terjamin.

Sistem pengukuran kinerja model Performance Prism berupaya menyempurnakan modelmodel sebelumnya, model ini tidak hanya didasari oleh strategi tetapi juga memperhatikan kepuasan dan kontribusi stakeholder, proses dan kapabilitas perusahaan. Memahami atribut apa yang menyebabkan stakeholder (pemilik dan investor, pemasok, konsumen, tenaga kerja, regulator dan masyarakat sekitar) merasa puas dengan apa yang telah diberikan oleh perusahaan merupakan langkah penting dalam model Performance Prism. Untuk dapat mewujudkan kepuasan para stakeholder tersebut secara sempurna, maka pihak manajemen perusahaan perlu juga mempertimbangkan strategistrategi apa saja yang harus dilakukan, proses-proses apa saja yang diperlukan untuk dapat menjalankan strategi tersebut, serta kemampuan apa saja yang harus dipersiapkan untuk melaksanakannya.

Keberhasilan metode Performance Prism ini dalam meningkatkan kinerja perusahaan juga telah diketahui berdasarkan penelitian yang dilakukan oleh Neely dari Cranfield School of Management pada perusahaan logistik DHL dan Coca Cola. Pendekatan Integrated Performance Measurement Systems (IPMS) merupakan salah satu metode pengukuran kinerja perusahaan yang memperhatikan kebutuhan-kebutuhan dari setiap pihak-pihak yang berkepentingan (stakeholder), dan tetap memonitor posisi perusahaan terhadap pesaingnya (external monitor). IPMS sendiri dapat diterapkan pada perusahaan yang berorientasi untuk mendapatkan keuntungan secara optimal (profit oriented), maupun pada organisasi non profit.

Permasalahan yang terjadi adalah keterbatasan pengetahuan pengambil keputusan dalam memilih perangkat atau metoda pengukuran kinerja perusahaan yang sesuai dengan kebutuhan bisnis perusahaan. Dengan permasalahan ini, para pengambil keputusan perusahaan terkadang tidak merasa puas atas metoda pengukuran kinerja karena tidak mampu menyelesaikan masalah pengukuran kinerja perusahaan. Sehingga kinerja direksi dalam mengelola perusahaan hanya terbatas diukur pada kinerja keuangan semata, walaupun mereka memiliki kinerja lainnya sebagai pemicu meningkatnya kinerja keuangan.

Pertanyaan yang muncul adalah, bagaimana kriteria memilih model pengukuran kinerja perusahaan yang paling sesuai dengan kebutuhan perusahaan? Pertanyaan ini muncul karena masingmasing model pengukuran kinerja memiliki kelebihan dan kelemahan, namun demikian perlunya menetapkan kriteria dalam menentukan model pengukuran kinerja yang sesuai dengan peruntukan 
perusahaan. Kaplan dan Norton (1996) dan Neely et al (2000) mengungkapkan bahwa kriteria dalam memilih model pengukuran kinerja perusahaan saat ini tidak lagi terbatas pada aspek finansial saja, hal ini karena pengukuran kinerja perusahaan yang hanya memandang aspek keuangan belum representatif menggambarkan kinerja perusahaan secara keseluruhan.

Adanya perubahan lingkungan bisnis yang dinamis dan kondisi persaingan yang semakin kuat, maka perlunya sistem pengukuran kinerja perusahaan yang lebih terintegrasi antara aspek keuangan dan non-keuangan. Artinya, untuk menentukan model pengukuran kinerja perusahaan haruslah memiliki kriteria komprehensif dan terintegrasi antara aspek keuangan dan non-keuangan serta mempertimbangankan mempertimbangkan aspek internal dan eksternal. Ketiga peneliti tersebut mereferensikan tiga model sistem pengukuran kinerja terintegrasi yang populer dan digunakan secara luas di dunia industri yaitu: Balanced Scorecard dari Harvard Business School, Integrated Performance Measurement System (IPMS) dari Centre for Strategic Manufacturing University of Strathclyde, dan Performance Prism dari kolaborasi antara Accenture dengan Cranfield School of Management.

Penelitian ini bertujuan untuk memperbandingkan dari tiga model pengukuran kinerja tersebut berdasarkan kriteria komprehensif dan terintegrasinya antara aspek finansial dan non-finansial pada aspek lingkungan internal dan eksternal perusahan, sehingga bagi pengambil keputusan akan dapat menentukan sebuah sistem pengukuran kinerja yang sesuai dengan peruntukan perusahaan. Atas dasar tujuan tersebut, maka penelitian ini diharapkan dapat menjadi referensi bagi para pengambil keputusan dalam memilih metoda pengukuran kinerja perusahaan yang sesuai dengan bisnis perusahaan yang lebih komprehensif dan integratif.

\section{Kajian Pustaka}

\section{Kinerja Perusahaan}

Kinerja perusahaan adalah ukuran tingkat keberhasilan manajemen dalam mengelola sumberdaya keuangan perusahaan, terutama pada pengelolaan investasi sebagai upaya untuk menciptakan nilai bagi pemegang saham (Elizabeth, 2000). Artinya kinerja perusahaan merupakan indikator tingkatan prestasi yang dapat dicapai dan mencerminkan keberhasilan manajer/pengusaha. Sedangkan menurut Gibson (1998) kinerja merupakan hasil yang dicapai dari perilaku anggota organisasi. Jadi kinerja organisasi merupakan hasil yang diinginkan organisasi dari perilaku orangorang di dalamnya.

Pengertian kinerja seperti yang disampaikan oleh Kuncoro (2007) adalah hasil kerja yang dipengaruhi oleh struktur dan perilaku industri di mana hasil biasa diidentikan dengan besarnya penguasaan pasar atau besarnya keuntungan suatu perusahaan di dalam suatu industri. Namun agar lebih terinci, kinerja dapat pula tercermin melalui efisiensi, pertumbuhan (termasuk perluasan pasar), kesempatan kerja, prestise profesional, kesejahteraan personalia, dan kebanggaan kelompok. Pada praktiknya, ukuran kinerja dapat bermacam-macam, tergantung pada jenis industrinya. Pertama, ukuran kinerja berdasarkan sudut pandang manajemen, pemilik, atau pemberi pinjaman. Sehingga ukuran yang digunakan dapat berupa kinerja operasional seperti profit margin. Kedua, kinerja dalam suatu industri dapat diamati dengan nilai tambah, produktivitas, dan efisiensi.

Penilaian kinerja organisasi dapat ditinjau dari rasio keuangan perusahaan. Menurut Brigman (1995) profitabilitas merupakan ukuran keberhasilan operasi perusahaan. Perusahaan dianggap mempunyai keunggulan bersaing apabila mempunyai tingkat laba yang tinggi dari rata-rata tingkat laba normal. Tingkat laba ini dinyatakan dalam beberapa rasio seperti: rasio pengembalian aset (Return On Assets $=$ ROA), rasio pengembalian modal sendiri (Return On Equity = ROE) dan rasio pengembalian penjualan (Return On Sale = ROS). Namun saat ini pengukuran kinerja sudah lagi tidak terbatas pada pengukuran kinerja keuangan saja, namun lebih lengkap pada aspek non-keuangan, 
seperti kepuasan pelanggan dan karyawan serta internal proses bisnis. Artinya pengukuran kinerja bagi perusahaan masa depan telah diukur dengan berbagai aspek internal dan eksternal sehingga lebih komprehensif dan terintegrasi pada setiap aspek pengukurannya.

Menurut Neely et. al. (1995), saat ini, ada tiga model sistem pengukuran kinerja terintegrasi yang populer dan digunakan secara luas di dunia industri yaitu: Balanced Scorecard dari Harvard Business School, Integrated Performance Measurement System (IPMS) dari Centre for Strategic Manufacturing University of Strathclyde, dan Performance Prism dari kolaborasi antara Accenture dengan Cranfield School of Management. Ketiganya memenuhi keriteria pengukuran yang cukup lengkap yaitu komprehensif, intergratif, dan menilai aspek internal dan ekstrnal perusahaan.

\section{Balanced Scorecard}

Balanced Scorecard dikembangkan di Harvard Business School oleh Kaplan dan Norton (1992). Sampai saat ini Balanced Scorecard adalah model terpopuler untuk sistem pengukuran kinerja baru yang telah dikembangkan (Neely et al., 1995). Kerangka kerja Balanced Scorecard menggunakan empat perspektif dengan titik awal strategi sebagai dasar perancangannya. Adapun keempat perspektif tersebut meliputi: financial perspective, customer perspective, internal business process perspective dan learning and growth perspective. Keterkaitan antarobjektif dan ukuran kinerja dinyatakan dengan cause-and-effect relationship, di mana terjadi kulminasi kinerja pada financial perspective.

Balanced Scorecard memberikan para eksekutif sebuah kerangka kerja menyeluruh yang menerjemahkan visi perusahaan dan strategi perusahaan dan strategi usaha ke dalam sejumlah ukuran. Sistem ini menterjemahkan misi dan strategi perusahaan menjadi tujuan dan measure, serta mengorganisirnya menjadi empat perspektif yang berbeda (Kaplan dan Norton, 1992) yaitu: 1) Perspektif Finansial; 2) Perspektif Pelanggan; 3) Perspektif Proses Bisnis Internal; dan 4) Perspektif Proses Belajar dan Pertumbuhan.

Penjelasan masing-masing perspektif adalah sebagai berikut: (1) Finansial diperlukan untuk memberikan ringkasan dari konsekuensi ekonomi akibat dari kebijaksanaan-kebijaksanaan yang telah diambil. Aspek finansial ini erat hubungannya dengan profitabilitas, contoh pemasukan operasional, return on capital dan economic added value. (2) Pelanggan diperlukan untuk mengidentifikasi segmen pasar dan konsumen dimana unit kerjaakan saling bersaing dan tolak ukur yang akandipakai untuk mengukur segmen yang diinginkan. (3) Bisnis Internal diperlukan untuk mengidentifikasi internal business process yang kritis dan harus ditingkatkan. (4) Belajar dan Pertumbuhan diperlukan untuk mengidentifikasi infrastruktur dari organisasi yang harus dibangun untuk menghasilkan pertumbuhan dan perbaikan jangka panjang.

\section{Performance Prism}

Sistem pengukuran kinerja model Performance Prism merupakan penyempurnaan modelmodel sebelumnya diantaranya Balanced Scorecard. Model ini tidak hanya didasari oleh strategi tetapi juga memperhatikan kepuasan dan kontribusi stakeholder, proses, dan kapabilitas perusahaan (Nelly dan Adam, 2000). Memahami atribut apa yang menyebabkan stakeholder (pemilik dan investor, supplier, konsumen, tenaga kerja, pemerintah dan masyarakat sekitar) menjadi puas atas kinerja perusahaan adalah langkah penting dalam model Performance Prism. Dan untuk dapat mewujudkan kepuasan para stakeholder tersebut secara sempurna, maka pihakmanajemen perusahaan perlu juga mempertimbangkan strategi-strategi apa saja yang harus dilakukan, proses-proses apa saja yang diperlukan untuk dapat menjalankan strategi tersebut, serta kemampuan apa saja yang harus dipersiapkan untuk melaksanakannya.

Berbeda dengan sistem pegukuran kinerja Balance Scorecard, yang berpedoman pada ukuran kinerja harus diturunkan secara ketat dari strategi adalah tidak benar. Seharusnya, kebutuhan dan 
keinginan dari para stakeholders-lah yang harus diperhatikan pertama kali. Kemudian, baru strategi dapat diformulasikan. Hal ini karena Performance Prism mempunyai pandangan yang lebih komprehensif terhadap stakeholders (seperti investor, pelanggan, karyawan, peraturan pemerintah dan supplier) dibanding kerangka kerja lainnya. Metoda pengukuran kinerja ini menggambarkan kinerja organisasi sebagai bangun tiga dimensi yang memiliki lima bidang sisi, yaitu dari sisi kepuasan stakeholder, strategi, proses, kapabilitas, dan kontribusi stakeholder.

Dari sisi kepuasan Stakeholder, siapa saja stakeholder organisasi dan apa saja keinginan dan kebutuhan mereka? Stakeholder yang dipertimbangkan di sini meliputi konsumen, tenaga kerja, supplier, pemilik/investor, serta pemerintah dan masyarakat sekitar. Penting bagi perusahaan berupaya memberikan kepuasan terhadap apa yang diinginkan dan dibutuhkan stakeholder-nya serta melakukan komunikasi yang baik dengan mereka.

Dari sisi strategi, strategi apa yang dibutuhkan untuk memberikan kepuasan terhadap keinginan dan kebutuhan para stakeholder? Strategi dalam hal ini sangat diperlukan untuk mengukur kinerja organisasi sebab dapat dijadikan sebagai monitor (acuan) sudah sejauh mana tujuan organisasi telah dicapai, sehingga pihak manajemen bisa mengambil langkah cepat dan tepat dalam membuat keputusan untuk menyempurnakan kinerja organisasi.

Dari sisi proses, proses-proses apa saja yang dibutuhkan untuk meraih strategi yang sudah ditetapkan? Proses di sini diibaratkan sebagai mesin dalam meraih sukses: yaitu bagaimana caranya agar organisasi mampu memperoleh pendapatan yang tinggi dengan pengeluaran serendah mungkin melalui pemampatan fasilitas serta pengoptimalan saluran-saluran pengadaan (procurement) dan logistik.

Dari sisi kapabilitas, kemampuan-kemampuan apa saja yang dibutuhkan untuk menjalankan proses yang ada? Kapabilitas atau kemampuan di sini maksudnya adalah kemampuan yang dimiliki oleh organisasi meliputi keahlian sumber dayanya, praktek-praktek bisnisnya, pemanfaatan teknologi, serta fasilitas-fasilitas pendukungnya. Kemampuan organisasi ini merupakan pondasi yang paling dasar yang harus dimiliki oleh organisasi untuk dapat bersaing dengan organisasi-organisasi lainnya.

Dari sisi kontribusi Stakeholder, kontribusi apa yang dibutuh dan diinginkan dari para stakeholder untuk mengembangkan kemampuan yang perusahaan miliki? Untuk menentukan apa saja yang harus diukur yang merupakan tujuan akhir pengukuran kinerja dengan metoda Performance Prism ini, maka organisasi harus mempertimbangkan hal-hal apa saja diinginkan dan dibutuhkan dari para stakeholdernya. Sebab organisasi dikatakan memiliki kinerja yang baik jika mampu menyampaikan apa yang diinginkannya dari para stakeholder yang sangat mempengaruhi kelangsungan hidup organisasi mereka.

\section{Integrated Performance Measurement System (IPMS)}

IPMS adalah model sistem pengukuran kinerja yang dikembangkan di Center for Strategic Manufacturing (CSM) dari University of Strathclyde, Glasgow. Tujuan dari model IPMS agar sistem pengukuran kinerja lebih robust, terintegasi, efektif dan efisien. Berbeda dengan dua model sebelumnya, model ini menjadikan keinginan stakeholder menjadi titik awal di dalam melakukan perancangan sistem pengukuran kinerjanya. Stakeholder tidak berarti hanya pemegang saham (shareholder), melainkan beberapa pihak yang memiliki kepentingan atau dipentingkan oleh organisasi seperti konsumendan karyawan.

Model IPMS membagi level bisnis suatu organisasi menjadi 4 level, yaitu: Business (Corporate - Bisnis Induk), Business Unit (Unit Bisnis), Business Process (Proses Bisnis), dan Activity (Aktivitas Bisnis). Sehingga perancangan sistem penilaian kinerja dengan model IPMS harusmengikuti tahapan-tahapan sebagai berikut: identifikasi stakeholder dan requirement, melakukan 
External Monitor (Benchmarking), menetapkan objectives bisnis, mendefinisikan measure atau Key Performance Indicators (KPI), melakukan validasi KPI, dan spesifikasikan KPI.

\section{Konseptual Model}

Sesuai dengan tujuan penelitian, yaitu membandingkan sistem penilaian kinerja perusahaan yang dinilai berdasarkan tingkat komprehensif dan terintegratif antara aspek finansial dan nonfinansial pada lingkungan internal dan eksternal perusahaan, maka model konseptual yang digunakan dalam menilai ketiga sistem pengukuran kinerja tersebut seperti yang disampaikan pada bagan di bawah ini.

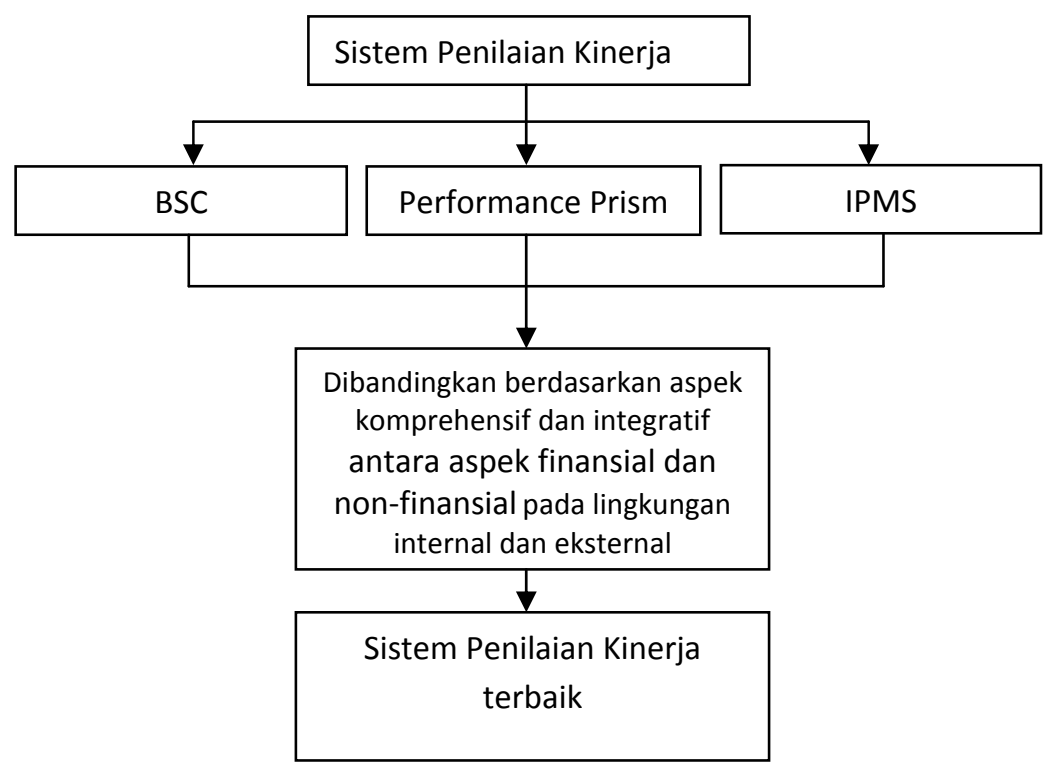

Gambar 1 Konseptual Model

\section{METODE}

Metode penilitian ini bersifat deskritif analitis yang merupakan penelitian yang bermaksud memberi gambaran terhadap suatu fenomenal atau permasalahan tertentu, dimana sudah ada informasi mengenai gejala tersebut, namun belum memadai, sehingga diperlukan penjelasan yang lebih rinci dengan melakukan penilaian dalam memilih sistem pengukuran kinerja perusahaan. Perolehan data akan dilakukan melalui metode riset kepustakaan (Library Research) dari berbagai text book dan jurnal-jurnal terkait dengan sistem penilaian kinerja perusahaan.

Untuk melengkapi keterbatasan informasi tersebut, peneliti melakukan survei di PT GIU dengan responden direksi dan manajer sebanyak 5 orang untuk memberikan skor penilaian atas krieria-kriteria pengukuran kinerja untuk ketiga sistem pengukuran kinerja perusahaan BSC, IPMS, dan Prims. Kriteria Sistem pengukuran pengukuran kinerja bagi perusahaan masa depan akan mengukur berbagai aspek internal dan eksternal sehingga lebih komprehensif dan terintegrasi pada antara aspek finansial dan non-finansial. Sehingga penelitian ini menggunakan dua kriteria utama, yaitu komprehensif dan integratif pada lingkungan eksternal dan internal. Skor penilaian untuk kedua kriteria tersebut terdiri atas lima tingkatan skor, yaitu 5 menyatakan Sangat Tinggi tingkat komprehensif atau integratif, 4 menyatakan Tinggi, 3 menyatakan Sedang, 2 menyatakan Rendah, dan 1 menyatakan Sangat Rendah. 


\section{HASIL DAN PEMBAHASAN}

Pengukuran kinerja bagi sebuah organisasi menjadi sangat diperlukan, karena pengukuran kinerja menjadi tolak ukur bagi pencapaian kinerja manajemen, selain itu untuk mengetahui pula seberapa jauh perjalanan organisasi dalam mencapai visi dan misi yang diraih. Penelitiaan ini lebih memfokuskan pada sistem penelitian kinerja yang lebih modern, artinya sebuah sistem penilaian kinerja yang tidak lagi terbatas hanya memandang indikator keuangan semata dalam melihat kinerja perusahaan, namun lebih luas lagi pada aspek non-finansial. Pengukuran kinerja modern lebih komprehensif dan integratif setiap aspek pengukurannya. Selain itu pula memperhatikan aspek-aspek eksternal perusahaan atau stakeholder yang meliputi konsumen, tenaga kerja, supplier, pemilik/investor, serta pemerintah dan masyarakat sekitar.

Berbagai macam model sistem pengukuran kinerja modern yang dapat digunakan untuk mengukur kinerja perusahaan. Namun semakin bagus sebuah model pengukuran kinerja akan semakin menuntut kelengkapan data dan kemampuan pemimpin dalam pengambilan keputusan. Seperti yang disampaikan oleh Kaplan dan Norton (1996); Ghalayini et. al., (1997); dan Nelly et. al (2000) bahwa kriteria dalam memilih model pengukuran kinerja perusahaan saat ini tidak lagi terbatas pada aspek finansial saja, tapi meluas pada aspek non-keuangan. Selain itu adanya perubahan lingkungan bisnis yang dinamis dan kondisi persaingan yang semakin kuat, maka perlunya sistem pengukuran kinerja perusahaan yang lebih lebih memperhatikan aspek eksternal perusahaan. Artinya, untuk menentukan model pengukuran kinerja perusahaan haruslah memiliki kriteria komprehensif dan terintegrasi antara aspek keuangan dan non-keuangan serta mempertimbangankan mempertimbangkan aspek internal dan eksternal. Ketiga peneliti tersebut mereferensikan tiga model sistem pengukuran kinerja terintegrasi yang populer dan digunakan secara luas di dunia industri yaitu: Balanced Scorecard dari Harvard Business School, Integrated Performance Measurement System (IPMS) dari Centre for Strategic Manufacturing University of Strathclyde, dan Performance Prism dari kolaborasi antara Accenture dengan Cranfield School of Management.

Berdasarkan hasil penilaian yang melibatkan lima responden pengambil keputusan di PT GIU dengan kriteria penilaian aspek komprehensif dan integratif antara aspek finansial dan non-finansial pada lingkungan internal dan eksternal perusahaan, maka penelitian ini akan memperbandingkan ketiga sistem penilaian kinerja yang telah dikemukakan di atas. Perbandingan berdasarkan kelebihan dan kelemahan dari ketiga sistem tersebut seperti yang disampaikan pada tabel di bawah ini.

Tabel 1 Skor Penilaian Tiga Sistem Pengukuran Kinerja

\begin{tabular}{|c|c|c|c|c|}
\hline \multirow{2}{*}{$\begin{array}{l}\text { Sistem } \\
\text { Pengukuran } \\
\text { Kinerja }\end{array}$} & \multicolumn{3}{|c|}{ Skor Penilaian } & \multirow[b]{2}{*}{ Keterangan } \\
\hline & Komprehensif & Integratif & $\begin{array}{l}\text { Total } \\
\text { Skor }\end{array}$ & \\
\hline BSC & 3.60 & 4.60 & 8.20 & $\begin{array}{l}\text { BSC kurang komprehensif pada pengukuran kinerja } \\
\text { lingkungan eksternal, karena hanya mengukur aspek } \\
\text { pelanggan. Namun integratif pada keempat perspektif } \\
\text { pengukuranya }\end{array}$ \\
\hline Prism & 4.20 & 3.20 & 7.40 & $\begin{array}{l}\text { Lebih komprehensif dibandingkan BSC, namun } \\
\text { pengukuran internal belum difokuskan pada aspek kinerja } \\
\text { keuangan. Belum integratif ke aspek keuangan, karena } \\
\text { keuangan merupakan aliran darah bagi perusahaan }\end{array}$ \\
\hline IPMS & 4.40 & 3.40 & 7.80 & $\begin{array}{l}\text { Lebih komprehensif dan sangat sesuai bagi perusahaan } \\
\text { yang menerapkan jenjang bisnis. } \\
\text { Belum integraitif pada pengukuran kinerja keuangan. }\end{array}$ \\
\hline
\end{tabular}

Sumber: Hasil Penelitian, 2014 
Seperti yang disampaikan pada Tabel 1 di atas, BSC memiliki keunggulan dalam penilaian karena BSC memiliki keunggulan utama dalam pengukuran kinerja keuangan, walaupun BSC memiliki kelemahan dalam kriteria komprehensif karena pada aspek eksternal hanya mengukur kinerja pelanggan. Sedangkan Performace Prism dan IPMS memiliki kelebihan karena kedua sistem pengukuran ini lebih komprehensif dalam lingkungan eksternal sehinga pimpinan perusahaan dapat mengukur kinerja masa depan. Namun sayangnya kedua sistem pengukuran tersebut kurang komprehensif dan integratif dalam pengukuran lingkungan internal terutama pada aspek keuangan. Walau bagaimanapun kinerja keuangan sangat penting karena keuangan merupakan aliran darah bagi perusahaan.

Atas dasar hasil di atas dan hasil kajian literatur, maka dapat dilakukan analisis atas kelebihan dan kelemhan pada ketiga Sistem Pengukuran Kinerja yaitu BSC, Performance Prism, dan IPMS sebagai berikut.

Tabel 2 Perbandingan Kelebihan dan Kelemahan Tiga Sistem Pengukuran Kinerja

\begin{tabular}{|c|c|c|}
\hline $\begin{array}{c}\text { Sistem } \\
\text { Pengukuran } \\
\text { Kinerja }\end{array}$ & Kelebihan & Kelemahan \\
\hline \multirow[t]{2}{*}{ BSC } & $\begin{array}{l}\text { Komprehensif Lingkungan Eksternal-Internal } \\
\text { BSC memiliki empat perspektif pengukuran kinerja perusahaan } \\
\text { yang mencakup lingkungan internal dan eksternal. Lingkungan } \\
\text { eksternal diukur melalui perspektif pelanggan (dengan indikator } \\
\text { kepuasan pelanggan, loyalitas pelanggan, dan retensi pelanggan), } \\
\text { sedangkan tiga pespektif lainnya mengukur kinerja internal yaitu } \\
\text { Keuangan, Internal Bisnis Proses, dan Pertumbuhan \& } \\
\text { Pembelajaran. }\end{array}$ & $\begin{array}{l}\text { Komprehensif Lingkungan Eksternal-Internal } \\
\text { Bila dibandingkan dengan IPMS dan Prism, sistem } \\
\text { pengukuran kinerja BSC kurang lengkap pada pengukuran } \\
\text { kinerja lingkungan eksternal. BSC hanya mengukur aspek } \\
\text { pelanggan, sedangkan IPMS dan Prism, mengukur kinerja } \\
\text { aspek Stakeholders, sehingga cakupan eksternalnya lebih } \\
\text { luas. }\end{array}$ \\
\hline & $\begin{array}{l}\text { Integratif Lingkungan Eksternal-Internal } \\
\text { Keempat perspektif BSC saling integrative, karena memiliki sifat } \\
\text { kausalitas. DI awali dari perspektif paling bawah, yaitu } \\
\text { Pertumbuhan \& Pembelajaran, memiliki kausalitas ke atas yaitu } \\
\text { persepktif Proses Internal Bisnis, memiliki kausalitas ke atasnya } \\
\text { yaitu perspektif Pelanggan, dan terakhir adalah perspektif } \\
\text { Keuangan. }\end{array}$ & $\begin{array}{l}\text { Integratif Lingkungan Eksternal-Internal } \\
\text { Tidak ada kelemahan untuk aspek integratif, karena keempat } \\
\text { perspektif BSC telah disampaikan memiliki integrasi satu } \\
\text { sama lainnya. }\end{array}$ \\
\hline \multirow[t]{2}{*}{ Prism } & $\begin{array}{l}\text { Komprehensif Lingkungan Eksternal-Internal } \\
\text { SIstem pengukuran kinerja Prism lebih komprehensif } \\
\text { dibandingkan BSC karena dibangun atas tiga dimensi yang } \\
\text { memiliki lima bidang sisi, yaitu dari sisi kepuasan stakeholder, } \\
\text { strategi, proses, kapabilitas, dan kontribusi stakeholder. Namun } \\
\text { kelebihan utama yang dimiliki oleh sistem ini adalah penyusunan } \\
\text { strategi diawali dengan mengidentifikasi keinginan dan kebutuhan } \\
\text { stakeholders. Sedangkan BSC pengukuran kinerja diturunkan } \\
\text { berdasarkan penetapan strategi. }\end{array}$ & $\begin{array}{l}\text { Komprehensif Lingkungan Eksternal-Internal } \\
\text { Aspek pengukuran internal kurang difokuskan pada aspek } \\
\text { kinerja keuangan, karena tidak dapat dipungkiri bahwa aspek } \\
\text { keuangan merupakan darah bagi kelangsungan hidup } \\
\text { perusahaan. }\end{array}$ \\
\hline & $\begin{array}{l}\text { Integratif Lingkungan Eksternal-Internal } \\
\text { Integratif pada aspek lingkungan eksternal yang sangat luas, } \\
\text { karena mempertimbangkan keinginan dan kebutuhan seluruh } \\
\text { satuan stakeholders. }\end{array}$ & $\begin{array}{l}\text { Integratif Lingkungan Eksternal-Internal } \\
\text { Keseluruhan aspek pengukuran kinerja Prism belum } \\
\text { terintegrasi dengan aspek keuangan, karena aspek } \\
\text { pengukuran kinerja keuangan belum menjadi fokus yang } \\
\text { dipentingkan dalam Prism. }\end{array}$ \\
\hline IPMS & $\begin{array}{l}\text { Komprehensif Lingkungan Eksternal-Internal } \\
\text { IPMS membagi level bisnis suatu organisasi menjadi empat level, } \\
\text { yaitu:Business (Corporate - Bisnis Induk), Business Unit (Unit } \\
\text { Bisnis), Business Process (ProsesBisnis), dan Activity (Aktivitas } \\
\text { Bisnis). Lebih komprehensif dibandingkan BSC karena di dalam } \\
\text { proses identifikasi harus melibatkan indetifikasi stakeholder dan }\end{array}$ & $\begin{array}{l}\text { Komprehensif Lingkungan Eksternal-Internal } \\
\text { Pada lingkungan internal kurang tajam pada pengukuran } \\
\text { kinerja keuangan, karena uang merupakan aliran darahnya } \\
\text { perusahaan, sehingga bila tidak terukurnya kinerja keuangan } \\
\text { akan berdampak lemahnya pengendalian keuangan } \\
\text { perusahaan untuk cashflow dan investasi masa depan. }\end{array}$ \\
\hline
\end{tabular}

Integratif Lingkungan Eksternal-Internal

Belum terintegrasi dengan pengukuran kinerja keuangan sehingga sulit memprediksi kondisi keuangan saat ini dan masa mendatang. identifikasi stakeholder dan requirement, melakukan External Monitor (Benchmarking), menetapkan objectives bisnis, mendefinisikan measure atau Key Performance Indicators (KPI), melakukan validasi KPI, dan spesifikasikan KPI 
Seperti yang disampaikan pada tabel di atas, salah satu sistem pengukuran kinerja perusahaan yang paling popular saat ini adalah Balanced Scorecard, sistem ini memiliki karakteristik pengukuran paling lengkap karena memiliki dua dimensi pengukuran, yaitu eksternal dan internal atau biasa dikenal dengan empat perspektif pengukuran, yaitu perspektif pelanggan (dimensi eksternal) dan perspektif keuangan, internal proses, dan pertumbuhan dan pembelajaran (dimensi internal). Demikian halnya dua sistem pegukuran kinerja lainnya yaitu Performance Prism dan IPMS, keduanya melibatkan aspek pengukuran kinerja internal dan eksternal. Namun kelebihan utama yang dimiliki oleh BSC adalah adanya aspek pengukuran kinerja keuangan, di mana uang merupakan darah bagi perusahaan, sehingga menjadi penting untuk mengukur pencapaian kinerja keuangan perusahaan. Selain itu, tujuan utama dari sebuah perusahaan adalah mendapatkan keuntungan jangka panjang.

Performance Prism dan IPMS merupakan dua sistem pengukuran kinerja yang paling komprehensif dalam aspek lingkungan eksternal, yaitu pengukuran kinerja stakeholders, keduanya mementingkan bagaimana perusahaan dapat memberikan kontribusi dan kepuasan bagi stakeholdernya, sehingga keberadaan perusahaan di lingkungan eksternal sangat penting diukur untuk keberlangsungan jangka panjang perusahaan. Sedangkan BSC pengukuran kinerja eksternal hanya terbatas pada pengukuran kinerja Pelanggan saja.

Bila dibandingkan dengan Integrated Performance Measurement System (IPMS), Performance Prism memiliki kelebihan, yaitu dimana Key Performance Indicator (KPI) yangdiidentifikasikan terdiri dari KPI strategi, KPI proses, dan KPI kapabilitas yang merupakan hasil dari identifikasi terhadap stakeholder requirements serta tujuan perusahaan. Namun sebaliknya, IPMS langsung mengidentifikasikan KPI-nya berdasarkan stakeholder requirements serta tujuan perusahaan, tanpa memandang mana yang merupakan strategi, proses, dan kapabilitasperusahaan. Kelebihan utama dari IPMS adalah bila digunakan untuk pengukuran kinerja pada level unit bisnis yang terintegrasi dengan bisnis induknya. Konsep ini tidak akan dijumpai oleh model pengukuran kinerja lainnya.

Ketiga sistem tersebut memenuhi kriteria komprehensif dan integratif pada lingkungan eksternal dan internal. Ketiganya merupakan sistem pengukuran kinerja masa depan, namun adanya kelebihan dan kelemahan masing-masing sistem tersebut merupakan pilihan yang disesuaikan dengan kebutuhan perusahaan dan sang pengambil keputusan. Artinya perusahaan yang memilih salah satu sistem pengukuran kinerja bukan berarti perusahaan yang kurang baik atau karena ketiga sistem telah dipandang baik bila dinilai pada kriteria yang diteliti.

Sistem pengukuran kinerja mana yang paling baik dipilih bagi perusahaan? Tidak ada pilihan yang paling baik, namun yang ada adalah pilihan yang paling cocok bagi perusahaan. Perusahaan yang berfokuskan pada pengukuran lingkungan eksternal secara komprehensif, maka akan lebih cocok menggunakan Performance Prism dan IPMS, namun bila perusahaan tersebut menginginkan pengukuran kinerja pada jenjang tingkatan unit bisnis perusahaan, maka model IPMS yang cocok dipilih daripada Performance Prism. Selain itu, bagi perusahaan yang lebih mengedepankan pengukuran kinerja keuangan sebagai hasil akhir, maka pilihan BSC menjadi sangat cocok.

\section{SIMPULAN}

Dibandingkan Balanced Scorecard, model Performance Prism dan IPMS memiliki beberapa kelebihan diantaranya mengidentifikasi stakeholder dari banyak pihak yang berkepentingan, seperti pemilik dan investor, supplier, pelanggan, tenaga kerja, regulator dan masyarakat sekitar. Sedangkan Balanced Scorecard mengidentifikasikan stakeholder hanya dari sisi shareholder dan customer saja. Sedangkan bila dibandingkan dengan IPMS, Performance Prism memiliki kelebihan, yaitu Key Performance Indicator (KPI) yang diidentifikasi terdiri dari KPI strategi, KPI proses, dan KPI 
kapabilitas. Sebaliknya, IPMS langsung mengidentifikasikan beberapa KPI tanpa memandang mana yang merupakan strategi, proses, dan kapabilitas perusahaan.

Ketiga sistem pengukuran kinerja memiliki kelebihan dan kekurangan, namun demikian keputusan memilih sebuah sistem pengukuran kinerja sangat ditentukan oleh para eksekutif perusahaan, karena pilihan yang tepat adalah kecocokan di mana mereka dapat mengadopsi sebuah sistem pengukuran kinerja yang cocok dengan kondisi perusahaan dan tingkat kapabilitas pengambil keputusan. Semakin canggih sebuah sistem pengukuran kinerja menuntut kapabilitas yang tinggi bagi pimpinannya dalam mengumpulkan dan menggunakan data, serta pemahaman dalam penggunaannya.

\section{DAFTAR PUSTAKA}

Brigman. (1995). Social Psychology. Second Edition. New York: Harper Collins Publishers Inc.

Elizabeth. (2000). Hubungan laba akuntansi dan arus kas terhadap kinerja perusahaan. Jurnal Riset Akuntansi Indonesia, 6(2): 76-85

Gibson et al. (1994). Organisasi. Jilid 1. alih bahasa Agus Dharma. Jakarta: Erlangga.

Ghalayini, A. M., Noble, J. S., Crowe, T. C. (1997). An integrated dynamic performance measurement system for improving manufacturing competitiveness. International Journal of Production Economics, 48: 207-25.

Kaplan, R. S., Norton D. P. (1992). The Balanced Scorecard - Measures that DrivePerformance. Harvard Business Review. Jan-Feb, Boston, United States of America.

Kuncoro, M. (2007). Ekonomika Industri Indonesia: Menuju Negara Industri Baru 2030? Yogyakarta: Andi.

Neely, A.D., Gregory, M., Platts, K. (1995). Performance measurement system design: Aliterature review and research agenda. International Journal of Operations \& Production Management, 15(4): 80-116.

Neely, A.D., Adams, C.A. (2000). The Performance Prism in Practice, Centre for Business Performance. UK: Cranfield School of Management.

Parawiyati, Baridwan. (1998). Kemampuan Laba dan Arus Kas dalam memprediksi Laba danArus Kas Perusahaan Go Public di Indonesia. Jurnal Riset Akuntansi Indonesia, 1(1): 2-3. 